\title{
Perilaku Komunikasi dalam Proses Rehabilitasi Pecandu Narkoba di Rumah Sakit HB Sa'anin Padang
}

\author{
Neni Efrita ${ }^{1}$; Eliza ${ }^{2}$; Sulthan Jiyad Muqsith Asmara ${ }^{3}$ \\ Universitas Islam Negeri Imam Bonjol Padang \\ ${ }^{1}$ neniefrita@uinib.ac.id \\ ${ }^{2}$ elizamag@uinib.ac.id \\ ${ }^{3}$ sulthanjyd@gmail.com
}

\begin{abstract}
The process of rehabilitation of drug addicts in the Psychiatric Hospital in addition to medical and social processes, rehabilitation of drug addicts at the HB Sa'anin Padang Hospital also has used various forms of communication behavior to restore the health of drug addicts. The process of integrated treatment and recovery activities will be carried out if health workers and psychologists are skilled in communicating both verbally and nonverbally. The formulation of the problem in this research is how communication behavior in the process of rehabilitation of drug addicts at the Mental Hospital HB Sa'anin Padang. With the methodological approach used is qualitative, data collection through observation, interviews and documentation. The results showed: 1. Verbal communication behavior in the process of rehabilitation of drug addicts at the HB Sa'anin Psychiatric Hospital in Padang carried out by health workers is verbal communication behavior in the form of verbal words and written words, written words are used as guides to act and act in the rehabilitation process. 2. The behavior of nonverbal communication in the process of rehabilitation of drug addicts in the Psychiatric Hospital HB Sa'anin by health workers with drug addicts is in the form of artifactual (appearance), proxemic (physical distance) and paralinguistic (intonation and tone of voice).
\end{abstract}

Keyword : rehabilitation; communication behavior; health; drug addicts; health workers.

\begin{abstract}
ABSTRAK
Proses rehabilitasi pecandu narkoba di Rumahsakit Jiwa selain proses secara medis dan sosial, rehabilitasi pecandu narkoba di Rumahsakit Jiwa HB Sa'anin Padang juga telah memanfaatkan berbagai bentuk perilaku komunikasi untuk pemulihan kesehatan pecandu narkoba. Proses kegiatan pengobatan dan pemulihan secara terpadu akan dapat dilaksanakan apabila tenaga kesehatan dan psikolog terampil dalam melakukan komunikasi baik secara verbal maupun secara nonverbal. Rumusan masalah dalam penelitian ini adalah bagaimana prilaku komunikasi dalam proses rehabilitasi pecandu narkoba di Rumahsakit Jiwa HB Sa'anin Padang. Dengan pendekatan metodologis yang dipakai adalah kualitatif, pengumpul data melalui observasi, wawancara dan dokumentasi. Hasil penelitian menunjukkan: 1. Perilaku komunikasi verbal dalam proses rehabilitasi pecandu narkoba di Rumahsakit Jiwa HB Sa'anin Padang dilakukan oleh petugas kesehatan adalah prilaku komunikasi verbal dalam bentuk kata-kata lisan maupun melalui katakata tertulis, kata-kata yang tertulis dijadikan panduan untuk bertindak dan berbuat dalam proses rehabilitasi. 2. Perilaku komunikasi nonverbal dalam proses rehabilitasi pecandu narkoba di Rumahsakit Jiwa HB Sa'anin oleh petugas kesehatan dengan pecandu narkoba adalah dalam
\end{abstract}


bentuk kinesik (gerak tubuh) artifaktual (tampilan), proksemik (jarak fisik) dan paralinguistik (intonasi dan nada suara)

Keyword : rehabilitasi; prilaku komunikasi; kesehatan; pecandu narkoba; petugas kesehatan.

\section{PENDAHULUAN}

Mulai tahun 2015 BNN Kota dan kabupaten yang ada di Sumatera Barat telah sering berbicara tentang penyelamatan pecandu dan pengguna narkoba. Mayarakat kota Sumatera Barat telah sering mendengar kata-kata " Pecandu wajib direhabilitasi dan pengguna lebih baik di rehabilitasi sebab pecandu dan pengguna bukanlah pelaku kejahatan, mereka adalah korban dari bandar narkoba. Para penyuluh BNNP Sumatera Barat akan sering menyuarakan kata - kata tersebut untuk membantu warga Sumatera Barat supaya terbebas dari penyalahgunaan narkotika dan obat terlarang. Himbauan ini sesuai dengan UU Nomor 35 Tahun 2009 Tentang Narkotika pasal 54 yang berbunyi:Pecandu narkoba dan korban penyalahgunaan narkotika wajib menjalani rehabilitasi medis dan rehabilitasi sosial. Ketentuan tersebut didukung oleh 3 peraturan lain yakni sebagai berikut:

1. Peraturan Pemerintah Republik Indonesia Nomor: 25 Tahun 2011 Tentang Pelaksanaan Wajib Lapor Pecandu Narkotika

2. Keputusan Menteri Kesehatan Nomor 1305 tahun 2011; tentang penetapan Institusi Penerima Wajib Lapor (IPWL)

3. Kepmenkes Nomor 2171 tahun 2011 tentang; Tata Cara Wajib Lapor Pecandu Narkotika.

Proses kegiatan pengobatan dan pemulihan secara terpadu akan dapat dilaksanakan apabila tenaga kesehatan dan psikolog terampil dalam melakukan interaksi dan komunikasi baik secara verbal maupun secara nonverbal, karena proses rehabilitasi yang dilakukan merupakan proses komunikasi. Apapun bentuk aktivitas yang dilakukan oleh manusia, termasuk pengetahuan dan keterampilan yang dimiliki oleh manusia merupakan komunikasi dengan komunikasi manusia dapat berhubungan satu sama lain, tidak ada manusia yang tidak terlibat dalam komunikasi untuk memenuhi kebutuhannya sehari-hari.

Melalui komunikasi pelayan kesehatan akan selalu berinteraksi dengan pecandu narkoba dalam proses rehabilitasi. Dalam proses rehabilitasi pecandu narkoba ini akan terlihat perilaku komunikasi baik verbal maupun nonverbal. Perilaku komunikasi dalam penelitian ini adalah perilaku komunikasi yang disampaikan oleh pemberi layanan rehabilitasi dan pecandu narkoba, sedangkan yang peneliti maksud dengan pecandu narkoba adalah pecandu yang sedang menjalani proses rehabilitasi yang ada di Rumah Sakit Jiwa HB Sa'anin Padang.

Proses rehabilitasi pecandu narkoba di RSJ ini selain proses rehabilitasi secara medis dan rehabilitasi sosial, rehabilitasi pecandu narkoba di RSJ HB Sa'anin Padang juga telah memanfaatkan berbagai bentuk perilaku komunikasi untuk pemulihan kesehatan pecandu narkoba tersebut. Dalam proses komunikasi yang terjadi antara pemberi layanan kesehatan dan pecandu narkoba ini merupakan komunikasi antarpribadi yang terjadi ketika proses sosial di mana pemberi layanan kesehatan dan pecandu narkoba saling berinteraksi satu sama lain.

Dalam konteks proses rehabilitasi melalui komunikasi yang diberikan oleh pemberi layanan kesehatan lebih mengenal pecandu narkoba secara pribadi artinya ada ikatan psikologis yaitu mengenal kepribadiannya. Budhyatna (1994) mengatakan bahwa: "makin besar para pelaku komunikasi 
mengenal secara individu satu sama lain maka komunikasi tersebut makin bersifat "pribadi" sebaliknya makin kecil tingkat pengetahuan individu satu sama lain maka komunikasi itu terjadi makin bersifat "impersonal".

Sebagaimana dunia komunikasi dalam proses rehabilitasi pecandu narkobapun pemberi layanan kesehatan telah memakai teknik yang sama. Secara langsung ataupun tidak langsung ketika menggunakan komunikasi akan menggunakan pesan yang beragam baik verbal maupun non verbal bergantung pada konteks dan setting di mana komunikasi itu dilakukan.

Penelitian tentang prilaku komunikasi mungkin sudah banyak dilakukan namun penelitian tentang prilaku komunikasi dalam proses rehabilitasi pecandu narkoba belum bnyak dilakukan oleh peneliti lain. Penelitian ini perlu dilakukan kerena prilaku komunikasi dalam proses rehabilitasi pecandu narkoba dapat dilakukan unuk pemulilah kesehatan dan ketergantungan pecandu narkoba.

\section{METODE PENELITIAN}

\section{Paradigma Penelitian}

Penelitian ini bertolak dari paradigma kualitatif deskriptif, peneliti akan mendeskripsikan dan mengeksplorasikan serta menganalisis perilaku komunikasi baik perilaku verbal maupun perilaku komunikasi nonverbal syang terjadi dalam proses rehabilitasi pasien pecandu narkoba di RSJ HB Sa'anin Padang.

Dengan alat pengumpul data yang dipakai adalah observasiument penelitian, dalam observasi ini data yang dikumpulkan adalah perilaku komunikasi yang terjadi dalam proses rehabilitasi pesien pecandu narkoba baik perilaku komunikasi secara verbal maupun perilaku komunikasi secara nonverbal yang terjadi dalam proses rehabilitasi pasien pecandu narkoba yang ada di RSJ HB Sa'anin Padang.

Selain melalui observasi peneliti juga melakukan wawancara mendalam memperoleh data-data dari informan 7 orang dari petugas kesehatan terdiri dari 2 orang psikolog, 2 orang dokter 1 petugas Institusi Penerima Wajib Lapor orang dan 2 orang petugas kesehatan (Perawat) dan 5 orang dari residen (sebutan untuk pasien pecandu narkoba) dengan menggunakan kombinasi tehnik wawancara terbuka dengan dan petunjuk umum wawancara, dengan tehnik ini diharapkan informan dapat bebas mengemukakan pendapatnya tentang perilaku komunikasi yang dilakukan dalam proses rehabilitasi pasien pecandu narkoba di RSJ HB Sa'anin Padang yang berkaitan dengan perilaku komunikasi verbal dan nonverbal. Pengumpulan data ini juga dilakukan melalui dokumentasi.

Dokumen yang peneliti gunakan dalam penelitian ini adalah dokumen resmi yang terdiri dari dokumen internal dan eksternal. Dokumen internal merupakan aturan yang dikeluarkan oleh RSJ HB Sa'anin Padang yang terkait dengan proses rehabilitasi pecandu narkoba dan data pendukung lainnya yang ada hubungannya, sedangkan dokumen eksternal berisi bahan-bahan informasi yang dihasilkan oleh lembaga social, seperti buku, majalah, jurnal dan sumber tertulis lainnya yang dapat dimanfaatkan untuk menelaah perilaku komunikasi dan interaksi sosial dalam proses rehabilitasi pasien pecandu narkoba di RSJ HB Sa'anin Padang.

\section{Prosedur Pengumpulan Data}

Prosedur pengumpulan data penelitian ini: Penentuan lokasi penelitian,membangun akses, memilih sampling, pelaksanaan pengumpulan data, mencatat informasi, memecahkan isu lapangan, menyimpan data dan kembali kelangkah awal. 


\section{Pencatatan dan analisis data}

Pencatatan dan analisis data: Unitizing dan categorizing (induktif data analisis)yaitu dengan menggunakan analisis data yang bersifat induktif.Cara ini dilakukan agar data dapat digambarkan secara deskriptif, kaya data dan bersifat kontekstual. Pengolahan data dalam penelitian ini penulis lakukan melalui tiga kegiatan yang dilaksanakan secara bersamaan yaitu: reduksi data, penyajian data dan penarikan kesimpulan atau verifikasi ( Miles\&Hubermas dalam Rohidi;1992:18)

Pencatatan data field-notes diartikan sebagai proses pemilahan, pemusatanperhatian, pada penyederhanaan dan transformasi informasi dari rekaman data di lapangan. Pencatatan data berlangsung secara terus menerus selama kegiatan penelitian berlangsung. Pencatatan data di lapangan dilakukan dengan cara menggolongkan, mengarahkan dan mengorganisasikan informasi sedemikian rupa, sehingga kesimpulan finalnya dapat ditarik.

Penyajian informasi ini dimaksudkan untuk memahami apa yang sedang terjadi dan apa yang harus dilakukan, menganalisis atau mengambil tindakan berdasarkan pemahaman yang diperoleh dari penyajian data tersebut. Penyajian yang umum digunakan dalam penelitian kualitatif adalah dalam bentuk teks naratif. Teks tersebut masih terpencar, belum tersusun, untuk itu agar dapat melihat gambaran keseluruhannya, maka peneliti membuat berbagai macam matriks, grafik dan network. Dalam konteks penarikan kesimpulan atau verifikasi peneliti mencari makna dari setiap informasi yang dikumpulkan, untuk itu peneliti dapat mengumpulkan pola, tema hubungan, persamaan dan berbagai kemungkinan muncul dalam proses penelitian. Kesimpulan senantiasa diverivikasi selama penelitian berlangsung termasuk triangulasi, demikian kesimpulan yang semula tentative, kabur dan diragukan akan tetapi dengan bertambahnya informasi maka kesimpulan ini dapat menjawab persoalan.

\section{HASIL DAN PEMBAHASAN \\ PerilakuVerbal dalam Proses Rehabilitasi Pecandu Narkoba di Rumah Sakit Jiwa HB Sa'anin Padang}

Proses rehabilitasi yang dilakukan oleh petugas kesehatan kepada pecandu narkoba (selanjutnya peneliti sebut dengan residen) di Rumah Sakit Jiwa HB Sa'anin Padang ini menggunakan katakata secara lisan maupun kata-kata yang tertulis, pada umumnya antara petugas kesehatan selalu menggunakan bahasa sebagai alat komunikasi sehari-hari mereka ketika terjadi proses rehabilitasi. Selama ini bahasa verbal (kata-kata) digunakan oleh petugas kesehatan dan residen untuk berbagi pengalaman dan bertukar fikiran.

Melalui kata-kata lah petugas kesehatan mempengaruhi prilaku residen sehingga residen bisa berubah dari yang kurang baik menjadi baik, dari yang tidak suka menjadi suka, dari yang putus asa menjadi penuh harapan dan lain sebagainya. Dengan penyampaian kata-kata atau bahasa verbal yang disampaikan oleh petugas kesehatan kepada residen dalam proses rehabilitasi ini akan tercipta komunikasi yang efektif.

Dengan demikian dapat dikatakan bahwa proses rehabilitasi pecandu narkoba di Rumah Sakit Jiwa HB Sa'anin Padang ini dilakukan dengan menggunakan kata-kata atau komunikasi verbal karena bahasa verbal selama ini digunakan oleh orang untuk berbagi pengalaman, ide dan fikiran. Melalui bahasa verbal inilah seseorang dapat mempengaruhi perilaku orang lain dan disinilah letaknya kekuatan bahasa verbal itu. Bahasa memiliki banyak fungsi namun sekurang kurangnya ada tiga 
fungsi yang erat hubungannya dengan penciptaan komunikasi yang efektif diantara fungsi bahasa adalah untuk mempelajari dunia disekeliling, untuk membangun hubungan yang baik dengan sesama manusia dan menciptakan ikatanikatan dalam kehidupan manusia.

Penyampaian bahasa verbal dalam aktifitas komunikasi yang dilakukan oleh petugas kesehatan dan residen akan membentuk prilaku verbal itu sendiri, karena pada dasarnya perilaku verbal sebenarnya adalah komunikasi verbal yang menggunakan simbol atau pesan verbal dengan menggunakan kata-kata baik lisan maupun tulisan yang terjadi saat melakukan proses rehabilitasi.

Proses komunikasi yang dilakukan dalam rehabilitasi residen (sebutan untuk pasien pecandu narkoba) akan melibatkan proses komunikasi verbal yang selalu diikuti oleh perilaku verbal di antara petugas kesehatan dan residen. Meskipun perilaku komunikasi memungkinkan mempunyai makna bagi petugas kesehatan sebagai penerima oleh residen.

Proses rehabilitasi residen di RSJ HB. Sa'anin dilakukan dengan konsep therepeutic community (TC) adalah konsep yang dijalani dengan menolong diri sendiri yang dilakukan oleh sekelompok orang yang mempunyai masalah yang sama, mereka berkumpul untuk saling membantu dalam mengatasi masalah yag dihadapi, dengan kata lain man helping man to help himself yaitu seseorang menolong orang lain dengan menolong dirinya sendiri.

Konsep TC ini dapat dilakukan dengan adanya keyakinan bahwa:

1) Setiap orang bisa berubah

2) Kelompok bisa mendukung untuk berubah

3) Setiap individu harus bertanggung jawab

4) Progran terstruktur dapat menyediakan lingkungan aman dan kondusif bagi perubahan

5) Adanya partisipasi aktif.
Penerapan konsep TC ini dijalani oleh residen selama menjalani rehabilitasi. Ada beberapa fase yang harus dilalui oleh residen selama melakukan rehabilitasi di sini, pertama residen yang baru masuk ke rumah (sebutan untuk tempat dimana residen direhab) harus melalui fase "detox" fase ini dapat dijalani oleh residen selama mulai dari 10 hari sampai kurang dari satu bulan sesuai dengan kondisi residen itu. Seperti yang dikatakan oleh Chendra Fitra.

"Residen fase "detox" akan dirawat disini selama 10 hari atau kurang dari satu bulan sesuai dengan kondisi residen, tapi kebanyakan 10 atau 15 hari residen "detox" sudah bisa naik ke fase primary".(wawancara,tanggal 01 September 2018).

Untuk melihat perilaku komunikasi pada residen detox, peneliti memiliki keterbatasan untuk melakukan observasi karena residen ini berada pada ruangan khusus yang tidak boleh dimasuki oleh orang lain kecuali staf, dokter dan psikolog yang bertugas di ruanganinstalasi napza ini. Residen hanya berinteraksi dan berkomunikasi dengan staf sesuai dengan kebutuhan residen. Selain dengan staf residen detox boleh berkomunikasi dengan chief saja. Sementara residen lain yang sudah pada tingkat primary, younger, midlle dan older tidak boleh berinteraksi dan berkomunikasi dengan residen detox

Sesuai dengan konsep TC, bahwa setiap orang bisa berubah dan kelompok bisa mendukung untuk berubah maka residen detox juga termotivasi untuk merubah dirinya sendiri sehingga hanya membutuhkan waktu 10 hari dan atau kurang dari satu bulan residen detox bisa naik fase ke fase primary. Fase primary ini adalah fase di mana residen detox yang sudah melewati proses chair. Chair adalah sebutan untuk perenungan yang dilakukan residen detox untuk naik tingkat pada fase primary. Proses chair residen disuruh untuk merenung 
menghadap dinding kosong dengan posisi duduk setengah kursi dan punggung tidak boleh bersandar, tidak boleh menoleh kiri kanan dan tidak boleh berbicara, baik sendiri maupun dengan orang lain.

Proses chair ini selain dilakukan oleh residen detox yang mau naik fase, juga dilakukan oleh residen yang sudah diperbolehkan pulang. Namun waktu chairnya berbeda, untuk pasien detox waktunya dua jam sementara residen yang sudah boleh pulang waktu hanya 15 menit saja. Selama proses chair terlihat salah seorang residen detox menoleh ke kiri dan terdengar suara chief yang lumayan keras mengingatkan bahwa "tidak boleh menoleh dan nanti ditambah waktu selama lima menit" Ternyata kalau ada residen yang melanggar aturan chair akan ada penambahan waktu selama lima menit.

Proses chair selesai, selanjutnya residen yang dinyatakan bisa naik fase primary akan bergabung dengan residen dalam rumah primary yang mereka sebut dengan new admission (anggota baru yang bergabung di rumah primary). Anggota baru di rumah ini masih dalam tahap observasi lebih kurang 3-6 hari. Kalau anggota baru ini bisa menyesuaikan diri dengan residen lain yang ada dalam rumah, maka anggota baru ini bisa bergabung dengan seluruh residen yang ada di rumah ini.

Residen yang akan pulang dan telah selesai melewati tahap chair, selanjutnya memasuki sesi group kepulangan. Dalam sesi ini semua residen berkumpul dan berdiri membentuk lingkaran di luar ruangan yang dipimpin oleh COD (Coordinator of Departement. Selain itu, sesi ini juga dihadiri oleh salah seorang staf. COD memulai sesi ini dengan mengucapkan salam. Saling memberi nasehat, motivasi yang dilakukan secara verbal baik dalam bentuk lisan maupun tulisan. Prilaku verbal secara tulisan ini ditulis oleh residen yang akan pulang dengan menulis 10 keinginan dan 10 poin apa yang didapatkan dari rumah ini.

Kegiatan sesi grup kepulangan diakhiri dengan saling bersalaman dan berangkulan antara residen yang akan pulang dengan residen lainnya. Selanjutnya berdoa dan mengucapkan doa kedamaian diucapkan dengan suara lantang dan keras serta semangat.

" God, please grant me the serenity to accept the thing I can not change courage to change the things that I can and wisdom to know the difference".

"Tuhan, berikanlah kami kedamaian untuk dapat menerima apa yang tidak dapat kami ubah keberanian mengubah apa yang dapat kami ubah serta kebijaksanaan untuk dapat mengetahui perbedaannya".

Karena bahasa memiliki banyak fungsi diantaranya adalah untuk mempelajari dunia sekeliling kita, untuk membina hubungan yang baik diantara sesama, untuk menciptakan ikata-ikatan dalam kehidupan manusia. Karena simbol verbal akan selalu digunakan orang untuk berkomunikasi, bila semua kata yang digunakan hanya merujuk pada pada objek maka masalah komunikasi akan menjadi sederhana. Sebenarnya kata-kata juga merujuk pada peristiwa, sifat sesuatu, tindakan, hubungan, konsep dan lain-lain. Karena itulah sebagai seorang komunikator membutuhkan kecermatan menyiapkan pesan agar pesan verbal yang disampaikan dapat diterima oleh komunikannya. Liliweri (2001:193-194) penyampaian pesan lebih banyak menggunakan pesan verbal yakni bahasa karena itu komunikator membutuhkan:

Sesuai dengan apa yang telah penulis jabarkan di atas bahwa prilaku verbal ada yang berbentuk kata-kata yang disampaikan secara lisan maupun secara tulisan. Berdasarkan observasi, di rumah sakit ini juga membuat beberapa aturan yang harus dilakukan oleh residen untuk pedoman berperilaku: di antaranya adalah: peraturan utama yang harus diperhatikan, dipedomani, diikuti dengan 
perilaku residen. Peraturan utama ini terpampang di banyak dinding dengan tujuan agar residen mengikuti peraturan utama tersebut.

\section{Perilaku Nonverbal dalam Proses Rehabilitasi Pecandu Narkoba di Rumah Sakit Jiwa HB Sa'anin Padang.}

Perilaku komunikasi non verbal dalam proses penyembuhan pasien pecandu narkoba di RSJ HB Sa'anin Padang ini yang peneliti temui di lapangan dapat digambarkan dalam bentuk kinesik, proksemik, kronemik, tampilan atau artifaktual dan paralinguistic.

\section{a. Kinesik}

Pesan atau perilaku facial yang terjadi dalam proses rehabilitasi pecandu narkoba di RSJ HB sa'anin Padang dapat dikategorikan sebagai komunikasi yang simpati dan empati ini terlihat ketika salah seorang staf menasehati residen bagaimana dia harus bersikap dan tidak mengulangi perbuatan yang melanggar aturan.

Dalam sesi pemberian nasehat tersebut staf mengatakan kepada residen "ingat orang tuamu jangan pernah menyakiti hatinya selama ini dia telah menyayangimu dengan penuh kasih". Disisi lain terlihat bebearapa residen dengan serius mendengarkan nasehat yang disampaikan olehh staf namun ada juga beberapa residen yang tertunduk dengan wajah yang kelihatan sedih.

Selain prilaku fasial dengan wajah penyesalan dan sedih residen di rumah inipun akan menunjukkan prilaku facial ini yang menunjukan wajah simpati dan menyenangkan terlihat ketika residen melakukan sesi break, dalam kegiatan ini banyak diantara residen yang menampilkan facial yang menyenangkan diantaranya ketika dia asyik memakan makanan ringan sambil minum susu ataupun kopi termasuk ketika mereka merokok, hampir semua rsiden ketika bertemu dengan teman-temannya dalam berbagai aktivitas komunikasi akan selalu tersenyum dan menunujukan wajah yang ceria semua itu menandakan kebahagaian yang terpancar dari wajah residen.

Pesan atau perilaku gestural yang terlihat pada proses rehabilitasi di instalasi napza ini menunjukan gerakan sebagian badan ketika berkomunikasi, ini dapat dilihat ketika residen ingin menyampaikan pendapatnya dihadapan residen lainnya dengan mengacungkan tangan dan mengarahkan pandangan kepada chief. Perilaku seperti ini menunjukan perilaku yang menyenangkan karena ketika residen mengacungkan tangannya sama sekali dia tidak berbicara apa-apa.

Disisi lain terlihat juga bahwa ada di antara residen yang ketika bertemu dengan dokter atau psikolog mau masuk ruang tindakan ia sedikit membungkukan badan sebelum memasuki ruangan tindakan dokter ataupun psikolog. Sedangkan pesan atau perilaku postural yang terlihat diruangan ini ketika residen sedang istirahat duduk dikursi sambil goyang-goyang kaki dan posisi duduknya sangat santai sekali, ketika morning meeting hampir semua residen menunjukan perilaku postural yang cukup santai.

Selain itu gerakan tubuh seperti gambaran di atas yang terlihat dalam proses rehabilitasi pecandu narkoba di rumah sakit ini adalah:

\section{1) Emblim.}

Prilaku non verbal emblin bisa digambarkan ketika kepala ruangan melakukan sidak ke ruangan rawat inap residen, kerika itu kepala ruangan memberikan isyarat "ok" dengan mengacungkan jempolnya ketika melihat rungan bersih dan melambaikan tangan "isyarat kemarilah" yang ditujakan kepada chief. Banyak prilaku nonverbal emblim ini terjadi ketika proses rehab terjadi diantaranya: "jangan ribut" dengan meletakkan jari telunjuk pada 
bibir, membuat seperti lingkaran diantara jari telunjuk dan ibu jari dengan jari tengah, jari manis serta jari kelingking dibiarkan terbuka menunjukan isyarat:"ok" maupun isyarat 'the best'.

Selain itu emblim juga terlihat ketika residen "menundukkan wajahnya" ke bawah, prilaku seperti ini menandakan dia lagi sedih ada depresi. Emblin adalah isyarat non verbal pengganti kata-kata atau ungkapan tertentu.

\section{2) Ilustrator}

Ilustrator adalah prilaku non verbal yang menyertai dan secara harfiyah "mengilustrasikan" pesan verbal. Ketika residen mengatakan saya lapar dia akan "meraba perutnya sambil menunduk" ilustrator seperti ini menggambarkan kalau dia sedang lapar. Ketika jam istirahat banyak sekali ilustrator ini digunakan di antaranya adalah residen yang mau rokok dia akan "menaruh dua jarinya dan menempelkannya ke mulut', ada yang melalukan gerakan seperti orang lagi senam ini juga menandakan saya lelah dan ingin rilex sebentar. Masih banyak lagi prilaku non verbal ilustrator ini dilakukan oleh residen ataupun oleh staf di rumah sakit ini: gerakan tangan berputar menggambarkan buat lingkaran, melambaikan tangan melambangkan sampai jumpa dan lain-lain sebagainya.

\section{3) Regulator}

Dalam proses rehabilitasi pecendu narkoba di RSJ ini prilaku regulasi ini juga sering terlihat ketika seorang residen sedang bercerita kepada staf, terlihat staf menganggukkan kepala, menyesuiakan fokus mata yang mengarah kepada residen, begitu juga residen ketika mendengarkan pengarahan dari chief, sebenarnya dia tidak pasif, ketika apa yang dikatakan oleh chief benar menurut residen, dia akan menganggukkan kepala, melakukan kontak mata ketika melakukan percakapan, ekspresi wajah dan gerakan tangan dan lain sebagainya. Ini sesuai dengan apa yang dikatakan oleh DeVito (1997) bahwa Regulator adalah prilaku non verbal yang mengatur, memantau dan memelihara atau mengendalikan pembicaraan orang lain.

\section{4) Afffect display}

Affek display ini merupakan gerakan wajah yang mengandung makna emosional, gerakan emosional ini akan terlihat ketika orang sedang marah, takut, gembira dan sedih. Begitu juga ketika orang lagi bersemangat atau sedang kelelahan akan terlihat pada ekspresi wajahnya. Affek display ini biasanya akan membuka rahasia seseorang tanpa disadarinya.

Dalam proses rehabilitasi di sini affek display akan sering terlihat ketika ada residen yang melakukan kesalahan atau melanggar aturan yang sudah diberlakukan disini. Contoh: ketika staf memanggil seorang residen dan staf mengatakan bahwa residen melakukan "sneaky" (melakukan sesuatu hal dengan cara diam-diam) residen terlihat takut, begitu juga ketika residen akan terlihat sedih ketika dia menyadari bahwa mereka merasa bersalah yang disebabkan oleh prilaku negatifnya. Ada juga affek display gembira yang yang terpancar dari wajah residen ketika dia akan pulang dan dijemput oleh keluarganya termasuk resien yang diberi rewad untuk kenaikan fase dari midle ke fase older. Kegembiraan ini terpancar dari wajahnya karena residen yang sudah melewati fase midle ke fase older ini akan mendapatka beberapa fasilitas seperti: jatah rokok dari tiga batang perhari dinaikan menjadi enam batang perhari, dari yang tidak boleh melakukan komunikasi melalui telepon, sekarang sudah boleh melalukan hubungan dengan keluarga melalui telepon walaupun didampingi oleh staf ataupun konselor. Affek display ini merupakan prilaku komunikasi nonverbal yang dapat mengkomunikasikan berbagai gerakan 
wajah yang menyatakan emosional seseorang.

\section{Proksemik}

Proksemik merupakan pesan non verbal yang mempelajari posisi tubuh ataupun jarak tubuh (ruang antar tubuh) ketika komunikasi berlangsung. Konsep ruang menjadi penting ketika komunikasi sedang berlangsung dalam konteks proksemik proses komunikasi tidak hanya dipengaruhi oleh orang-orang yang terlibat dalam percakapan tetapi juga orientasi fisik dan status mereka.

Penggunaan dan pengaturan ruang dalam proses rehabilitasi di rumah sakit ini dilakukan dalam bentuk fase jarakjauh, fase jarak jauh ini biasanya dikaitkan dengan orang-orag yang harus berbicara lebih keras dibanding dengan mereka yang ada pada fase dekat. Kategori fase jauh ini menggambarkan banyak percakapan yag dilakukan oleh residen dihampir semua kegiatan. Sementara itu fase jarak dekat juga terjadi antara staf dengan residen antara residen dan dokter dan antara residen dengan psikolog, fase jarak dekat ini memungkinkan setiap orang yang terlibat dalam komunkasi masih dapat melihat secara keseluruhan bentuk wajah termasuk pakaian yang dipakai oleh residen.

Penggunaan dan pengaturan ruang dalam proses rehabilitasi juga dilakukan dalam bentuk fase jarak jauh. Fase jarak jauh biasanya dilakukan ketika staf, chief ataupun COD harus berbicara lebih keras ketika memanggil residen lainnya salah satu contoh chief menyuruh semua residen untuk berkumpul biasanya chief akan berebicara lebih keras untuk mengumpulkan residen agar dapat berkumpul dididalam ruangan yang telah ditentukan.

Perilaku komunikasi dalam pengaturan dan penggunaan ruang dalam proses rehabilitasi pecandu narkoba di rumah sakit ini tidak hanya dalam zona proksemik ada elemen lain yaitu teritoriality (kewilayahan). Kewilayahan merupakan kepemilikan seseorang atas wilayah atau area atau benda. Ada tiga jenis wilayah yaitu primer, sekunder dan publik (altma, 1975 ; lyman \& Scott 1990) wilayah primer wilayah ekslusif seseorang misalnya ruangan kerja dokter, ruangan kerja psikolog, ruangan kepala dan wakil kepala, kamar-kamar residen semua itu merupakan wilayah primer. Wilayah sekundder menunjukan wilayah personel seseorang dalam sebuah area atau benda, wilayah sekunder yang terlihat diruangan instalasi napza yang banyak digunakan oleh residen adalah tempat tidurnya, almari pakaiannya, hampir semua residen tidak merasa bahwa tempat tidur dan almari pakaian adalah miliknya tetapi dia bisa memanfaatkan fasilitas itu sementara waktu selama mereka melakukan rehabilitasi.

\section{Kronemik}

Merupakan studi tentang konsep tentang waktu. Konsep tentang waktu antara satu kelompok dengan kelompok lainnya tidak akan sama sesuai dengan regulasi yang ada pada kelompok itu. Konsep waktu yang ada dalam kegiatan rehabilitasi pecandu narkoba boleh dikategorikan dengan konsep waktu tepat waktu, konsep tepat waktu ini dapat terlihat dalam Schedule kegiatan harian residen

\section{Artifaktual}

Artifaktual diungkapkan melalui penampilan tubuh, pakaian dan kosmetik. Walaupun bentuk tubuh relatif menetap orang seringkali berperilaku dalam hubungan dengan orang lain sesuai dengan persepsinya tentang tubuhnya (body image). Erat kaitannya dengan tubuh adalah upaya membentuk citra tubuh dengan pakaian dan kosmetik. Pakaian menyampaikan pesan. Pakaian terlihat sebelum suara terdengar pakaian tertentu berhubungan perilaku tertentu. Umumnya pakaian digunakan untuk 
menyampaikan identitas seeorang untuk mengungkapkan pada orang lain siapa kita. Menyampaikan identitas berarti menunjukan kepada orang lain bagaimana perilaku kita dan bagaiamana orang lain sepatutnya memperlakukan kita, selain itu pakaian yang dipakai juga untuk menyampaikan perasaan, status, peranan dan formalitas.

Artifaktual yang terlihat disini selalu menampilkan tubuh ataupun pakaian sesuai dengan aturan yang sudah berlaku dirumah ini, karena penampilan merupakan penyampian perasaan, status dan peranan serta formalitas sehingga penampilan merupakan perilaku komunikasi non verbal residen juga menyesuaikan penampilannya sesuai dengan tempat dimana dan dalam situasi seperti apa harus berpenampilan contoh staf dan dokter pada hari-hari tertentu akan mamakai pakaian seragam yang telah ditetapkan oleh pihak rumah sakit sementara residen boleh berpakaian bebas tetapi harus bersih dan rapi. Pada hari sabtu dan minggu staf dan petugas yang ada di instalasi ini berpakaian bebas tapi sopan, biasanya staf laki-laki memakaia kaos/ kemeja dan celana panjang sedangkan staf atau petugas perempuan memakain pakaian yang menutup aurat atau berjilbab. Pakaian residen selalu terlihat bersih dan rapi karena memang rumah sakit mensyaratkan setiap residen harus berpakaian bersih dan rapi. Pakaian juga harus disesuaikan dengan kegiatan yang akan dilakukan oleh residen diataranya ketika olahraga berpakaian olahraga, ketika hari jumat berpakaian muslim, ke mesjidpun harus berpakaian muslim semua penghuni rumah ini tanpa kecuali selalu memperhatikan penampilannya mereka berusaha untuk menampilkan diri sebaik mungkin agar disukai dan disenangi oleh semua residen, staf, dokter dan psikolog yang bertugas disini.
Proses rehabilitasi pecandu narkoba di rumah sankit HB Sa'ani ini memiliki kecapatan berbicara sedang, nada cenderung rendah, intensitas suara juga sedang, instonasi suara datar dan tinggi, kualitas vokal juga cukup jelas dan kadang-kadang menggunakan dialek daerah/bahasa daerah dibeberapa tempat terjadinya peristiwa komunikasi.

Kecepatan berbicara sedang terlihat pada proses rehabilitasi ketika terjadi proses konseling, antara psikolog dan residen dalam proses terapi konseling suara antara psikolog dan reseden intensitas suara yang terdengar adalah intensitas berbicara sedang.

Selain intensitas suara datar dan sedang, intensitas suara tinggi juga terjadi dalam proses rehabilitasi pecandu narkoba di rumah sakit ini, intensitas suara tinggi akan tergambar ketika residen mengucapkan ikrar, memanggil untuk berkumpul dan menegur residen yang sedang bermenung.

\section{CONCLUSION / KESIMPULAN}

Prilaku komunikasi verbal dalam proses rehabilitasi pecandu narkoba di Rumah Sakit Jiwa HB Sa'anin Padang yang dilakukan oleh petugas kesehatan adalah prilaku komunikasi verbal dalam bentuk prilaku komunikasi melalui kata-kata secara lisan maupun melalui kata-kata yang tertulis, kata-kata yang tertulis ini dijadikan panduan untuk bertindak dan berbuat.

Prilaku komunikasi nonverbal dalam proses rehabilitasi pecandu narkoba yang terjadi di Rumah Sakit Jiwa HB Sa'anin yang dilakukan oleh petugas kesehatan dengan pecandu narkoba adalah dalam bentuk kinesik (gerak tubuh) artifaktual (tampilan), proksemik (jarak fisik) dan paralinguistik (intonasi dan nada suara).

Paralinguistic.

\section{DAFTAR KEPUSTAKAAN}


Andi Hamzah; 1994, Kejahatan Narkotika dan Psikotropika, Jakarta, Sinar Grafika.

A.W. Wijaya; 1985, Masalah Kenakalan Remaja dan Penyalahgunaan Narkotika, Bandung, Armico.

Bogdan, Robert \& Taylor, Steven J. 1975, Introduction to Qualitative Research Methods : A Phenomenological Approach to Social Science, New York: A Wiley Intersience Publication.

Bungin, Burhan, 2009, Penelitian Kualitatif Jakarta Kencana Prenada Media Group.

Devito, Joseph. A, 1997, Komunikasi Antar Manusia, kuliah dasar edisi ke 5 penerj Agus Maulana, Jakarta, professional Books

Gatot Supramono; 2001, Hukum Narkoba Indonesia, Jakarta, Penerbit Jembatan.

Hari Sasangka,2003, Narkotika dan Psikotropika dalam Hukum Pidana, Bandung; Mandar Madju.

Littlejohn, Stephen W. 2005. Theories of Human Communication. Belmond: Wadsworth Publishing Company.

Littlejohn, Stephen W. A. Foss, Karen 2010. Teori Komunikasi. Jakarta: Salemba Humanika.

Mulyana, Deddy dan Salatun. 2007. Metode Penelitian Komunikasi. Bandung. PT. Remaja Rosdakarya.

Moleong, Lexy.J. 2010. Metode Penelitian Kualitatif. Bandung. PT. Remaja Rosdakarya.

Mardani, 2008; Penyalahgunaan Narkoba (dalam Perspektif Hukum Islam dan Hukum Pidana Nasional), Jakarta; Rajawali Pers.

M. Taufik Mahakarao, dkk; 2009, Tindak Pidana Narkotika; Jakarta, Ghalia Indonesia.

Ruben, Brent, 1992, Communication and Human Behavior, New Jersey, rentice Halls Belton California, Wadswort'h Publishing Company
Subagyo Protodihardjo, 2000, Kenali Narkotika dan Penyalahgunaannya, PT. Gelora Aksara Pratama, Jakarta.

Sunaryo Siswanto, 2004; Penegakan Hukum Psikotropika dalam Kajian Sosiologi Hukum : Jakarta, Raja Grafindo Persada.

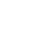

